\section{Inequalities in multimorbidity among elderly: a population-based study in a city in Southern Brazil}

\author{
Desigualdades na ocorrência de multimorbidade \\ entre idosos: um estudo populacional em um \\ município no Sul do Brasil
}

\section{Desigualdades en multimorbilidad entre ancianos: estudio basado en la población de una ciudad del sur de Brasil}

\author{
Caroline dos Santos Costa 1 \\ Thaynã Ramos Flores 1 \\ Andrea Wendt 1 \\ Rosália Garcia Neves 1 \\ Elaine Tomasi 1 \\ Juraci A. Cesar 1 \\ Andrea Dâmaso Bertoldi 1 \\ Virgílio Viana Ramires 2 \\ Bruno Pereira Nunes 1
}

\begin{abstract}
Lower socioeconomic level is positively related to multimorbidity and it is possible that the clustering of health conditions carries the same association. The aim of this study was to identify prevalence of multimorbidity and clusters of health conditions among elderly, as well the underlying socioeconomic inequalities. This was a cross-sectional population-based study carried out with 60-year-old individuals. Multimorbidity was defined as the presence of 2+, $3+, 4+$ or $5+$ health conditions in the same individual. Schooling levels and the National Economic Index were used to investigate inequalities in the prevalence of multimorbidities among elderly. Slope and concentration indexes of inequality were used to evaluate absolute and relative differences. A factorial analysis was performed to identify disease clusters. In every ten older adults, about nine, eight, seven and six presented, respectvely, 2+, 3+, 4+ and $5+$ health conditions. Three clusters of health conditions were found, involving musculoskeletal/mental/functional disorders, cardiometabolic, and respiratory factors. Higher inequalities were found the higher amount of health conditions (5+), when considering economic level, and for 3+, 4+ and 5+, when considering educational level. These findings show high multimorbidity prevalence among elderly, highlighting the persistence of health inequalities in Southern Brazil. Strategies by the health services need to focus on elderly at lower socioeconomic levels.
\end{abstract}

Multimorbidity; Social Inequity; Aged

\section{Correspondence}

C. S. Costa

Universidade Federal de Pelotas.

Rua Marechal Deodoro 1160, Pelotas, RS 96020-220, Brasil. carolinercosta@gmail.com

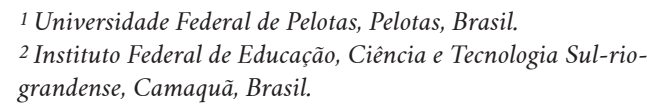

1 Universidade Federal de Pelotas, Pelotas, Brasil. 2 Instituto Federal de Educação, Ciência e Tecnologia Sul-riograndense, Camaquã, Brasil. 


\section{Introduction}

Life expectancy has been increasing globally, from 65.3 years in 1990 to 71.5 years in 20131 . In the same period, however, disability-adjusted life years (DALY) - a measure of the number of years lost to disease, disability or early death 2 - have also risen, especially due to noncommunicable diseases (NCDs) ${ }^{1}$. Thus, the aging phenomenon is accompanied by a higher disease burden, leading to greater demands on the health system 1 .

The motivation behind NCD research has largely been an aging population. However, these diseases rarely occur in an isolated or individual manner, and the clustering of health conditions seems to share a causal relationship with NCD prevalence, involving diseases, treatments, and the interaction of risk factors 3,4. Multimorbidity, the coexistence of multiple health conditions in the same individual, is common mainly in elderly 5 , increasing hospitalization risk 6 , worsening quality of life 7 and increasing health system costs 8 .

Studies on the prevalence of multimorbidity are marked by high heterogeneity, due to differences in the amount of health conditions evaluated, as well as in the cut-off points employed to define multimorbidity ( $\geq 2$ or $\geq 3$ conditions) 9 . A systematic review shows a $13 \%$ to $72 \%$ variability in the prevalence of multimorbidities in the overall population, while, in the elderly, most studies show a prevalence between 60 and $70 \% 10$.

Socioeconomic characteristics are associated to the occurrence of multimorbidities 11,12, and it is possible that the clustering of health conditions is affected by socioeconomic factors. According to the literature, lower socioeconomic levels are positively related to multimorbidity $3,13,14$. The association between socioeconomic disadvantages and worse health status may be explained by the existence of financial barriers that could be important to healthcare access and information 15 .

Researchers who investigate inequalities usually study isolated diseases, in terms of, for example, higher chances of developing oral cancer 16 or being depressed 17 in groups at lower socioeconomic levels. Furthermore, evaluated studies investigating sets of multiple diseases did not use formal statistical tests such as the slope index of inequality and the concentration index, the two major indices used in epidemiologic studies for the measurement of socioeconomic inequalities in health. Therefore, the aim of this study was to identify the prevalence of multimorbidity and clusters of health conditions among elderly, in relation to the underlying socioeconomic inequalities.

\section{Methods}

This was a cross-sectional, population-based study carried out with $\geq 60$-year-old individuals from the urban area of Pelotas, a city in the South of Brazil, in 2014. According to the census of 2010, carried out by the Brazilian Institute of Geography and Statistics (IBGE) 18, at that time there were 46,099 elderly living in the urban area of Pelotas.

Sample selection was performed in two stages: in the first, the census tracts were selected and, in the second, systematic selection of households was performed within each tract. Considering that this article is part of a larger research project (COMO VAI? - Consórcio de Mestrado Orientado para a Valorização da Atenção ao Idoso; Master's Consortium Aimed at Valuing Care for the Elderly), a sample of nearly 1,600 elderly was established in order to achieve the general research goals. Thus, 133 tracts and 3,745 households were selected, and all residents $\geq 60$ years old were invited to participate. For elderly who were unable to respond to the questionnaire, the caregivers' answers were used. Institutionalized elderly were not eligible.

All the interview and anthropometric measures were carried out by a trained and standardized team. Data collection lasted six months, and data entry was done using laptops. Interviews that the team was unable to perform after three or more attempts (different days and shifts) were considered losses. Quality control was carried out by fieldwork supervisors in 10\% of the sample, using a 19-item questionnaire containing timeless questions. This methodological approach has been previously applied; more details can be found in another publication 19.

The "multimorbidity" outcome was measured through the following health conditions: high blood pressure, diabetes, heart problem, heart failure, asthma, bronchitis, emphysema, arthritis, Par- 
kinson's disease, kidney failure, hypercholesterolemia, seizure, stomach ulcer, osteoporosis, urinary incontinence, constipation, fecal incontinence, depression, glaucoma, deafness, difficulty swallowing, insomnia, fainting, rhinitis, difficulty speaking, stroke, obesity, mental disorders and cancer. All health conditions were self-reported by the elderly based on medical diagnosis, except obesity, which was diagnosed by measuring height and weight and obtaining a body mass index equal to or over $30 \mathrm{~kg} / \mathrm{m}^{2}$. This set of health conditions was chosen because all are considered factors in the elderly's quality of life. Amounts of health conditions defined by the cut-off points $2+, 3+, 4+$ and $5+$ were considered multimorbidity 10,20 .

Sex (male/female), age (60-69; 70-79; $\geq 80$ years old), race/ethnicity (white; black; brown; indigenous; yellow), per capita monthly income, educational level (none; 1-3 years; 4-7; 8-10; 11 or more years) and National Economic Index (Índice Econômico Nacional - IEN, in quintiles: the first quintile corresponding to the poorest and the fifth to the richest) 21 were used to describe the sample. Educational level and IEN were used to investigate inequalities in the prevalence of multimorbidity among elderly.

Data were analyzed using Stata program, version 12.1 (https://www.stata.com). First, prevalence and $95 \%$ confidence intervals $(95 \% \mathrm{CI}$ ) of outcome and independent variables were obtained, as well as the mean and standard deviation (SD) of continuous variables. A factorial analysis 22 was then performed to identify disease clusters, and the component numbers were chosen from eigenvalues higher than one. Health conditions with loads higher than 0.3 were considered part of the same group. After the first evaluation of the model, some variables were excluded (Parkinson, kidney failure, seizure, fecal incontinence, fainting and difficulty speaking) in order to obtain a better model fit to the KaiserMeyer-Olkin and Bartlett sphericity tests $23,24,25$. For each participant of the study, a binary variable was created, indicating whether the participant had two or more diseases included in each disease set.

To measure inequalities in multimorbidity at different cut-off points, two indexes were calculated: the slope index of inequality (SII) and the concentration index (CIX) 26,27. The SII presents the absolute difference in percentage points (varying from -100 to $+100 \%$ ) between the poorest and richest quintiles of the IEN and the lowest and highest level of schooling using a logistic regression model. SII positive results indicate higher frequency in the richest or at the highest level of schooling. The CIX presents a relative difference based on a scale from -1 to +1 , with positive values indicating higher concentration of an outcome in the richest or at the highest level of schooling. To facilitate comprehension, CIX values were multiplied by 100 . For both measures, zero represents a distribution without inequalities in the IEN or schooling. Socioeconomic inequalities were investigated in relation to the multimorbidity cut-off points and the disease clusters obtained from factorial analysis - we analyzed the occurrence of two or more diseases out of all morbidities included in each cluster.

The study was approved by the Ethics Research Committee of the Faculty of Medicine, Federal University of Pelotas (number: 201324538513.1.0000.5317). The interviews were carried out only after signing of a Free and Informed Consent Form by the elderly or their caregiver.

\section{Results}

A total of 1,844 elderly were identified, and 1,451 were interviewed (78.7\% response rate). Among the sample, most were women (63\%), had between 60 and 69 years of age (52\%), were white (84\%), and had 4 to 7 years of schooling (31\%). The mean per capita income in the lower IEN quintile was BRL 746.25 (SD = BRL 378.72), and BRL 3,459.58 (SD = BRL 5,790.77) in the higher IEN quintile (Table 1).

High blood pressure (66.7\%), mental disorders (59.7\%), arthritis (41.4\%), insomnia (40.8\%) and hypercholesterolemia (40.7\%) presented the highest frequencies. The prevalence of $2+, 3+, 4+$ and $5+$ health conditions were $93.4 \%, 85.9 \%, 76.2 \%$ and $64.7 \%$, respectively (Table 2 ).

Regarding economic level, higher inequalities were found in elderly affected by rhinitis, depression and insomnia. For the last two, the highest prevalences were observed in the lower IEN quintile. For rhinitis, the highest prevalence was observed in the higher IEN quintile. Heart failure, constipation, arthritis, heart problem, hypercholesterolemia and the $5+$ set of health conditions presented lower inequalities. Remaining health conditions presented minimal inequalities (Figure 1a). 
Table 1

Sample description. Pelotas, Rio Grande do Sul State, Brazil, $2014(n=1,451)$.

\begin{tabular}{|c|c|c|c|}
\hline Variable & $\mathbf{n}$ & $\%$ & $95 \% \mathrm{Cl}$ \\
\hline \multicolumn{4}{|l|}{ Sex } \\
\hline Male & 537 & 37.0 & $34.5-39.5$ \\
\hline Female & 914 & 63.0 & $60.5-65.5$ \\
\hline \multicolumn{4}{|l|}{ Age (years) } \\
\hline $60-69$ & 756 & 52.3 & $49.7-54.9$ \\
\hline $70-79$ & 460 & 31.8 & $29.4-34.2$ \\
\hline $80+$ & 230 & 15.9 & $14.0-17.8$ \\
\hline \multicolumn{4}{|l|}{ Race/Ethnicity } \\
\hline White & 1,211 & 83.8 & $81.9-85.7$ \\
\hline Black & 168 & 11.6 & $10.0-13.3$ \\
\hline Brown/Indigenous/Yellow & 66 & 4.6 & $3.5-5.6$ \\
\hline \multicolumn{4}{|l|}{ Educational level (years) } \\
\hline 0 & 196 & 13.6 & $11.9-15.4$ \\
\hline $1-3$ & 337 & 23.5 & $21.3-25.7$ \\
\hline $4-7$ & 445 & 30.9 & 28.6-33.4 \\
\hline $8-10$ & 143 & 10.0 & $8.4-11.5$ \\
\hline \multirow[t]{2}{*}{$11+$} & 316 & 22.0 & 19.9-24.1 \\
\hline & $\mathbf{n}$ & Mean & SD \\
\hline \multicolumn{4}{|c|}{ Per capita monthly income (by IEN quintile) } \\
\hline 1st (lowest) & 274 & 746.25 & 378.72 \\
\hline $2^{\text {nd }}$ & 265 & 932.34 & 880.80 \\
\hline $3 r d$ & 271 & $1,142.49$ & 909.58 \\
\hline 4 th & 269 & $1,451.57$ & $1,332.38$ \\
\hline $5^{\text {th }}$ (highest) & 268 & $3,459.58$ & $5,790.77$ \\
\hline
\end{tabular}

95\%Cl: 95\% confidence interval; IEN: National Economic Index; SD: standard deviation.

Regarding educational level, higher inequalities were found for higher amounts of diseases: rhinitis, depression, urinary incontinence, constipation, insomnia, heart problem, deafness, mental disorders and for the sets of $3+, 4+$ and $5+$ health conditions. For all these diseases, higher prevalences were observed in the lower educational level quintile, except for rhinitis, which had higher prevalence in the higher educational level quintile. Difficulty swallowing, glaucoma, osteoporosis, heart failure, emphysema, bronchitis, cancer, stroke, arthritis, diabetes, obesity, high blood pressure and the set of $2+$ health conditions presented lower inequalities. Remaining health conditions presented minimal inequalities (Figure 1b).

Factorial analysis showed three main clusters of health conditions. The first includes arthritis, urinary incontinence, constipation, osteoporosis, depression, difficulty swallowing, mental disorders, and insomnia (eigenvalue $=4.14 ;$ musculoskeletal $/ \mathrm{mental} /$ functional disorders factor). The second is composed by high blood pressure, diabetes, heart problem, heart failure, and stroke (eigenvalue $=$ 1.79; cardiometabolic factor). The third includes asthma, bronchitis, emphysema, and rhinitis (eigenvalue $=1.35$; respiratory factor). Hypercholesterolemia, stomach ulcer, glaucoma, deafness, cancer, and obesity were not part of any group (Table 3).

Inequalities were also evaluated through SII (absolute inequalities) and CIX (relative inequalities). Some inequalities were found in the relationship between multimorbidity prevalence and economic/ educational level. In respect to economic level, the inequality was towards the poor (higher prevalence of multimorbidity among the poorer population) for $5+$ health conditions and for the musculoskeletal/mental/functional disorders factor. In respect to educational level, inequality towards the poor was observed for 3+, 4+ and 5+ health conditions and for the cardiometabolic and musculoskeletal/ 
Table 2

Frequency (\%) of morbidities included in the study. Pelotas, Rio Grande do Sul State, Brazil, $2014(n=1,451)$.

\begin{tabular}{|c|c|c|c|c|}
\hline Variables & $\mathbf{n}$ & Cases & $\%$ & $95 \% \mathrm{Cl}$ \\
\hline High blood pressure & 1,447 & 965 & 66.7 & $64.3-69.1$ \\
\hline Mental disorders & 1,445 & 863 & 59.7 & $57.2-62.3$ \\
\hline Arthritis & 1,446 & 599 & 41.4 & $38.9-44.0$ \\
\hline Insomnia & 1,447 & 591 & 40.8 & $38.3-43.4$ \\
\hline Hypercholesterolemia & 1,446 & 589 & 40.7 & $38.2-43.3$ \\
\hline Depression & 1,442 & 516 & 35.8 & $33.3-38.3$ \\
\hline Heart problem & 1,446 & 465 & 32.2 & $29.8-34.6$ \\
\hline Constipation & 1,444 & 462 & 32.0 & 29.6-34.4 \\
\hline Deafness & 1,446 & 452 & 31.3 & 28.9-33.7 \\
\hline Urinary incontinence & 1,447 & 436 & 30.1 & $27.8-32.5$ \\
\hline Obesity & 1,364 & 408 & 29.9 & $27.5-32.3$ \\
\hline Osteoporosis & 1,444 & 365 & 25.3 & $23.0-27.5$ \\
\hline Diabetes & 1,447 & 340 & 23.6 & $21.3-25.7$ \\
\hline Rhinitis & 1,443 & 276 & 19.1 & $17.1-21.2$ \\
\hline Stroke & 1,447 & 170 & 11.8 & $10.1-13.4$ \\
\hline Stomach ulcer & 1,446 & 169 & 11.7 & $10.0-13.4$ \\
\hline Bronchitis & 1,446 & 166 & 11.5 & $9.8-13.1$ \\
\hline Heart failure & 1,442 & 157 & 10.9 & $9.3-12.5$ \\
\hline Cancer & 1,447 & 147 & 10.2 & $8.6-11.7$ \\
\hline Difficulty swallowing & 1,447 & 117 & 8.1 & $6.7-9.5$ \\
\hline Glaucoma & 1,444 & 102 & 7.1 & $5.7-8.4$ \\
\hline Emphysema & 1,446 & 94 & 6.5 & $5.2-7.8$ \\
\hline Asthma & 1,445 & 93 & 6.4 & $5.2-7.7$ \\
\hline Fecal incontinence & 1,447 & 88 & 6.1 & $4.9-7.3$ \\
\hline Fainting & 1,447 & 88 & 6.1 & $4.9-7.3$ \\
\hline Difficulty speaking & 1,446 & 74 & 5.1 & $4.0-6.3$ \\
\hline Kidney failure & 1,444 & 58 & 4.0 & $3.1-5.0$ \\
\hline Seizure & 1,447 & 43 & 3.0 & $2.1-3.9$ \\
\hline Parkinson's disease & 1,445 & 22 & 1.5 & $0.9-2.2$ \\
\hline Multimorbidity (2+) & 1,343 & 1,246 & 93.4 & $91.9-94.8$ \\
\hline Multimorbidity (3+) & 1,343 & 1,148 & 85.9 & $84.0-87.7$ \\
\hline Multimorbidity (4+) & 1,343 & 1,014 & 76.2 & $73.9-78.4$ \\
\hline Multimorbidity (5+) & 1,343 & 853 & 64.7 & $62.0-67.4$ \\
\hline
\end{tabular}

95\%Cl: 95\% confidence interval.

mental/functional disorders factors. Inequalities for $2+$ health conditions and for the respiratory factor were not observed, regardless of the socioeconomic indicator (Table 4).

\section{Discussion}

These results show high prevalence of multimorbidities among elderly. Only $6.6 \%$ of the sample had zero or only one health problem. For every ten older adults, nine, eight, seven and six presented $2+$, $3+, 4+$ and $5+$ health conditions, respectively. Three clusters of health conditions were found, involving the following disorders: musculoskeletal/mental/functional, cardiometabolic and respiratory. Higher inequalities were found for a higher amount of health conditions (5+) when considering the economic level, and for 3+, 4+ and 5+ health conditions when the educational level was evaluated. 
Figure 1

Frequency (\%) of diseases and multimorbidity according to economic $(n=1,271)$ and educational $(n=1,329)$ levels. Pelotas, Rio Grande do Sul State, Brazil, 2014.

1a) Economic level
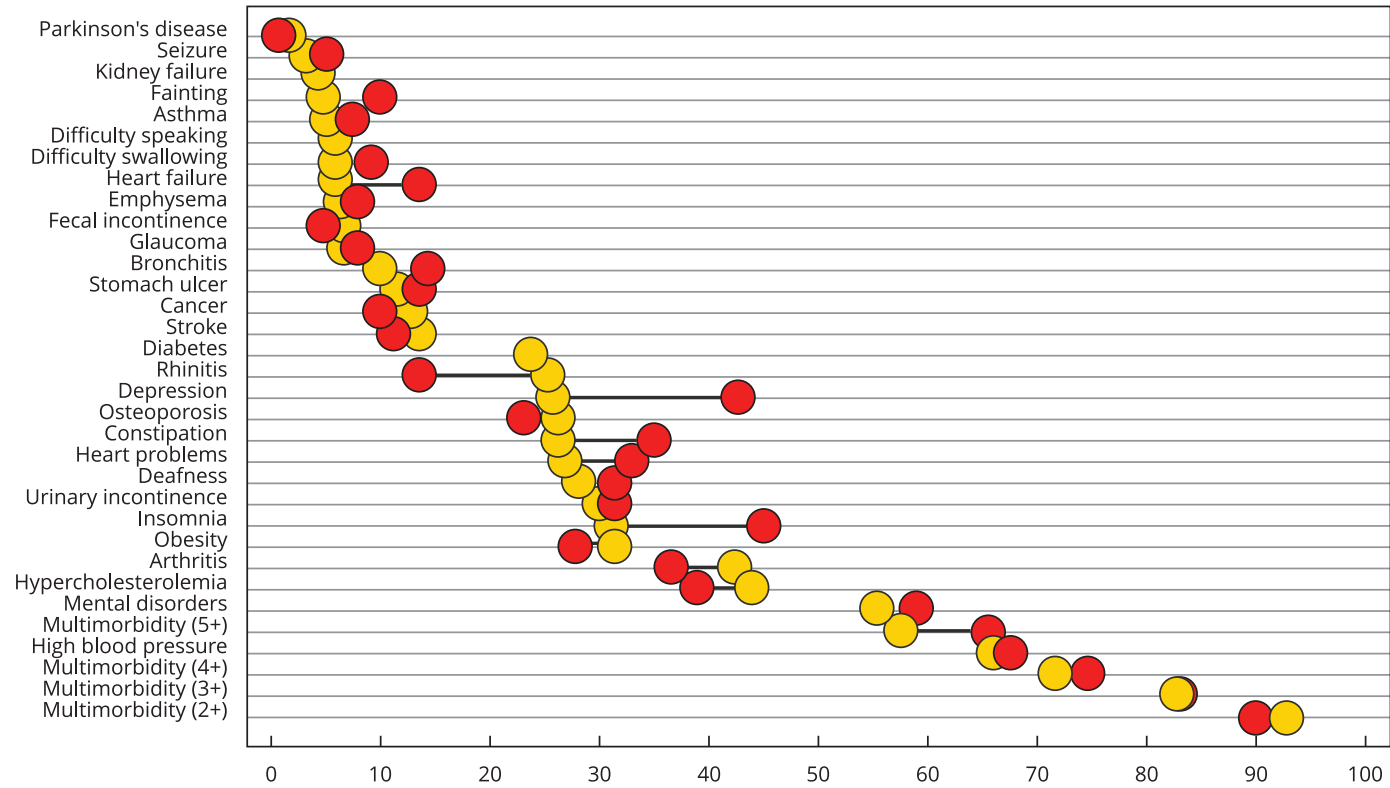

1b) Educational level
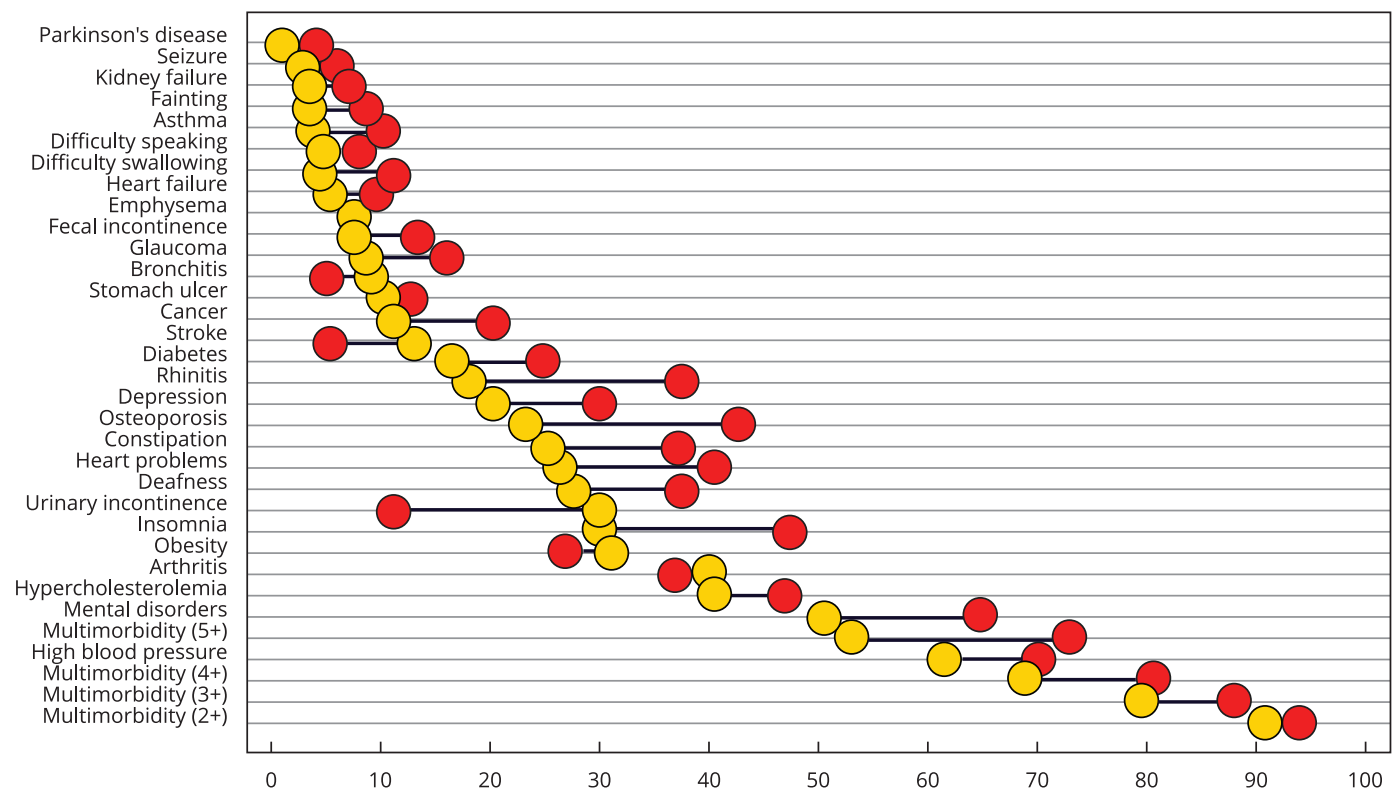

Difference between lowest and highest economic level

Lowest
Highest

Lowest

Highest 
Table 3

Factorial analysis. Pelotas, Rio Grande do Sul State, Brazil, $2014(n=1,343)$.

\begin{tabular}{|c|c|c|c|}
\hline Morbidities & $\begin{array}{c}\text { Factor } 1 \\
\text { Musculoskeletal/Mental/Functional } \\
\text { disorders }\end{array}$ & $\begin{array}{c}\text { Factor } 2 \\
\text { Cardiometabolic }\end{array}$ & $\begin{array}{c}\text { Factor } 3 \\
\text { Respiratory }\end{array}$ \\
\hline Arthritis & 0.55 & & \\
\hline Urinary incontinence & 0.52 & & \\
\hline Constipation & 0.60 & & \\
\hline Osteoporosis & 0.54 & & \\
\hline Depression & 0.51 & & \\
\hline Difficulty swallowing & 0.54 & & \\
\hline Mental disorders & 0.64 & & \\
\hline Insomnia & 0.54 & & \\
\hline High blood pressure & & 0.62 & \\
\hline Diabetes & & 0.38 & \\
\hline Heart problem & & 0.76 & \\
\hline Heart failure & & 0.80 & \\
\hline Stroke & & 0.42 & \\
\hline Asthma & & & 0.89 \\
\hline Bronchitis & & & 0.89 \\
\hline Emphysema & & & 0.59 \\
\hline Rhinitis & & & 0.38 \\
\hline Hypercholesterolemia & - & - & - \\
\hline Stomach ulcer & - & - & - \\
\hline Glaucoma & - & - & - \\
\hline Deafness & - & - & - \\
\hline Cancer & - & - & - \\
\hline Obesity & - & - & - \\
\hline Eigenvalue & 4.14 & 1.79 & 1.35 \\
\hline Explained variance \% * & $0.43(0.37)$ & $0.19(0.29)$ & $0.14(0.27)$ \\
\hline Kaiser-Meyer-Olkin & 0.65 & & \\
\hline
\end{tabular}

* Before oblique rotation (after oblique rotation).

\section{Table 4}

Absolute (slope index of inequality - SII) and relative (concentration index - CIX) inequalities of multimorbidity and its clusters according to economic level $(n=1,359)$ and educational level $(n=1,422)$. Pelotas, Rio Grande do Sul State, Brazil, 2014.

\begin{tabular}{|c|c|c|c|c|}
\hline \multirow[t]{2}{*}{ Variables } & \multicolumn{2}{|c|}{ Economic level } & \multicolumn{2}{|c|}{ Educational level } \\
\hline & SII $(95 \% \mathrm{CI})$ & $\mathrm{CIX}(95 \% \mathrm{Cl})$ & SII $(95 \% \mathrm{CI})$ & $\mathrm{CIX}(95 \% \mathrm{Cl})$ \\
\hline Multimorbidity (2+) & $0(-6 ; 5)$ & $0(-1 ; 1)$ & $-2(-7 ; 3)$ & $0(-1 ; 0)$ \\
\hline Multimorbidity (3+) & $-2(-9 ; 5)$ & $0(-2 ; 1)$ & $-9(-16 ;-2)$ & $-2(-3 ;-1)$ \\
\hline Multimorbidity (4+) & $-5(-14 ; 4)$ & $-1(-3 ; 1)$ & $-13(-21 ;-4)$ & $-3(-4 ;-1)$ \\
\hline Multimorbidity (5+) & $-13(-24 ;-4)$ & $-3(-6 ;-1)$ & $-21(-31 ;-12)$ & $-5(-8 ;-3)$ \\
\hline Respiratory factor & $-2(-7 ; 3)$ & $-4(-12 ; 5)$ & $-1(-5 ; 4)$ & $0(-9 ; 9)$ \\
\hline Cardiometabolic factor & $-6(-15 ; 4)$ & $-2(-6 ; 2)$ & $-20(-32 ;-10)$ & $-8(-12 ;-4)$ \\
\hline $\begin{array}{l}\text { Musculoskeletal/Mental/Functional } \\
\text { disorders factor }\end{array}$ & $-15(-24 ;-6)$ & $-3(-6 ;-1)$ & $-22(-30 ;-14)$ & $-5(-7 ;-3)$ \\
\hline
\end{tabular}

95\% Cl: 95\% confidence interval.

Note: values in bold correspond to significant differences. 
This study found a higher multimorbidity prevalence than other studies 28,29 . A population-based survey carried out in 2008 with older adults living in Bagé, a medium-sized city in Southern Brazil similar to Pelotas, observed that $81.3 \%$ (95\%CI: 79.3-83.3) of the participants had $2+$ morbidities and 64\% (95\%CI: 61.5-66.4) had 3+28. Afshar et al. 29 analyzed data on chronic diseases from 28 low and middle-income countries, deriving a worldwide standardized multimorbidity prevalence of $7.8 \%$ ( $\geq 2$ chronic conditions). The same study found a multimorbidity prevalence range of 3.1\% (95\%CI: 1.7-4.5, in Myanmar) to 45.1\% (95\%CI: 37.4-52.8, in Kazakhstan). For the Brazilian population, the prevalence was $28 \%$ (95\%CI: 23.7-32.3). This heterogeneity between studies in respect to prevalence may be due to the amounts of chronic conditions included, as well as the different cut-off points used to define multimorbidity.

Significant gender differences were not observed in the multimorbidity analysis (data not shown), and therefore stratified analysis was not performed. Van den Bussche et al. 30 also found insignificant gender differences in relation to number of chronic conditions. However, in other studies, larger gender differences were observed, varying according to the affected gender. Schäfer et al. 14 observed 0.27 less conditions in females, while Marengoni et al. 31 found an odds ratio of multimorbidity $50 \%$ higher in women than men. Fortin et al. 32 observed a multimorbidity prevalence ( $\geq 2$ diseases) 3.2 percentage points higher in women when compared to men in the general population; yet when the authors evaluated the practice-based population the multimorbidity prevalence was higher in men than women (5.8 percentage points). These differences could be due to the lower utilization of health services by men in the general population.

Simultaneous chronic conditions tend to be more commonly reported among obese than nonobese individuals 33 . However, the inclusion of obesity as a chronic condition in multimorbidity indexes is not established in the literature. Agborsangaya et al. 33 discussed obesity as an important risk factor for morbidity and all-cause mortality, highlighting the need for its inclusion in multimorbidity indexes. The American Medical Association (AMA), in its 2013 annual meeting, discussed that the recognition of obesity as a chronic medical condition could lead to greater investments by governments and the private sector for developing and reimbursing obesity treatments. On the other hand, this recognition could result in greater medicalization of obesity.

The first cluster of health conditions is the musculoskeletal/mental/functional disorders factor, including musculoskeletal problems, urinary incontinence, constipation, and difficulty swallowing. It is worth pointing out that this cluster also includes depression and mental disorders, which may be contributing to or causing these conditions. Despite the fact that this was an unexpected disease cluster, the conditions seem to share some causal relationship (e.g., diseases-diseases; treatment-treatment; certain risk factors). Garin et al. 34 found a "mental-articular" factor, which included arthritis and depression, and discussed the association between mental disorders and arthritis observed by a study carried out in 17 countries 35 . The other two factors (cardiometabolic and respiratory) observed in our study are largely found in the literature. For instance, Garin et al. 34, in a cross-sectional, population-based, multi-country study (China, Ghana, India, Mexico, Russia, and South Africa), Schäfer et al. ${ }^{14}$, with results from a cohort study carried out in Germany, and van den Bussche et al. 30 , using data from a cross-sectional study also carried out in Germany, observed similar clusters. Cardiometabolic and respiratory diseases are common in older adults because of the physiological changes that come naturally with the aging process. Furthermore, these diseases generally share the same risk factors, such as smoking, physical inactivity, unhealthy diet, and alcohol consumption 36,37 .

Although more than $90 \%$ of the elderly have at least two chronic diseases, no socioeconomic inequalities were found for the cut-off points of $2+$ and $3+$ health conditions. These findings may be explained by the population at lower economic and schooling levels being more affected by chronic diseases, due to their general health scenario: less access to and use of health services, and worse conditions for maintaining a healthy lifestyle 38,39. Also, according to the literature, the lower the socioeconomic condition, the higher the prevalence of multimorbidities 12,29 . It is important to highlight that inequalities related to schooling were higher compared to those related to economic level. It is possible that schooling has more influence in the elderly population because, despite of economic level, in the educational phase of active life this population was able to reach a schooling level lower than the current generation. 
A few studies have previously evaluated these indicators (economic and schooling levels) in relation to multimorbidity among elderly 12,29,40,41. However, they did not estimate inequalities using the SII and the CIX. The use of these indexes contributes to a more robust evaluation of health inequalities, and therefore this study presents a relevant contribution to the literature on this issue. Differences in the evaluation of inequalities notwithstanding, our findings are consistent with those of other studies which assessed socioeconomic inequalities in multimorbidity 12,29. It is important to highlight that multimorbidity was presented in terms of four different cut-off points, increasing the comparability between studies.

Some limitations should be mentioned. First, the health conditions included in this study were self-reported by the elderly. However, this limitation may be minimized by the fact that interviewees referred to actual medical diagnoses 42 . Despite the inequalities in the use of health services by different socioeconomic groups and differences in the elder's understanding of the doctor or health professional's diagnosis, in this study about $90 \%$ of the elderly visited a doctor in the last year (data not presented), minimizing the possibility of self-report bias. Sample selection was done in order to be representative of the original population, i.e., as bias-free as possible. Regarding losses and refusals (response rate of 78.7\%), significant differences were not observed for gender, when comparing to the included sample $(\mathrm{p}=0.198)$. However, the mean age was 69.5 years $(\mathrm{SD}=8.6)$ for losses and refusals, and $70.7(\mathrm{SD}=8.2)$ for the included sample, presenting a statistical difference $(\mathrm{p}=0.011)$. Despite this, the age difference was very low $(1.2 ; \mathrm{SD}=0.47)$. Regarding multimorbidity, some variables related to health problems had missing information (1,343 participants). This set of participants was compared to the included sample $(1,451)$ and there were no statistical differences for gender and age $(\mathrm{p}=0.474$ and $\mathrm{p}=0.226$, respectively).

\section{Conclusions}

Inequalities in the distribution of health conditions for both economic and schooling level were observed. In the absolute (SII) and relative (CIX) evaluations, inequalities were also observed for the different multimorbidity cut-off points investigated. The findings suggest that poorer and less educated elderly are more affected by multimorbidity when compared to richer and more educated elderly, except for the $2+$ health conditions cut-off point and for the respiratory factor. These findings highlight the persistence of health inequalities in Brazil, showing the importance of strategies that allow the health services to reach the most vulnerable portion of the elderly population, which often has the greatest difficulties in access and use of the health services as well as in the management of health conditions.

\section{Contributors}

C. S. Costa contributed to the study design, data analysis and interpretation, and article writing. T. R. Flores, V. V. Ramires, and B. P. Nunes contributed to the conceptualization and design, data analysis and interpretation, and article writing. A. Wendt, R. G. Neves, E. Tomasi, J. A. Cesar, and A. D. Bertoldi contributed to the data analysis and interpretation and critically revised the intellectual content. All authors approved the final version and are responsible for all aspects of the work in ensuring the accuracy and integrity of any part of the work.

\section{Acknowledgments}

We are grateful to the Brazilian Graduate Studies Coordinating Board (Capes; AUXPE - PROEX 1107/2013/grant number 23038.003968/2013-99) and to the Rio Grande do Sul State Research Foundation (FAPERGS) for the master's scholarships provided. 


\section{References}

1. Murray CJ, Barber RM, Foreman KJ, Abbasoglu Ozgoren A, Abd-Allah F, Abera SF, et al. Global, regional, and national disability-adjusted life years (DALYs) for 306 diseases and injuries and healthy life expectancy (HALE) for 188 countries, 1990-2013: quantifying the epidemiological transition. Lancet 2015; 386:2145-91.

2. Murray CJ, Vos T, Lozano R, Naghavi M, Flaxman AD, Michaud C, et al. Disability-adjusted life years (DALYs) for 291 diseases and injuries in 21 regions, 1990-2010: a systematic analysis for the Global Burden of Disease Study 2010. Lancet 2012; 380:2197-223.

3. Violan C, Foguet-Boreu Q, Flores-Mateo G, Salisbury C, Blom J, Freitag M, et al. Prevalence, determinants and patterns of multimorbidity in primary care: a systematic review of observational studies. PLoS One 2014; 9:e102149.

4. Sinnige J, Braspenning J, Schellevis F, StirbuWagner I, Westert G, Korevaar J. The prevalence of disease clusters in older adults with multiple chronic diseases - a systematic literature review. PLoS One 2013; 8:e79641.

5. Salive ME. Multimorbidity in older adults. Epidemiol Rev 2013; 35:75-83.

6. Macinko J, Camargos V, Firmo JO, Lima-Costa MF. Predictors of 10-year hospital use in a community-dwelling population of Brazilian elderly: the Bambuí cohort study of aging. Cad Saúde Pública 2011; 27 Suppl 3:S336-44.

7. Fortin M, Lapointe L, Hudon C, Vanasse A, Ntetu AL, Maltais D. Multimorbidity and quality of life in primary care: a systematic review. Health Qual Life Outcomes 2004; 2:51.

8. Glynn LG, Valderas JM, Healy P, Burke E, Newell J, Gillespie P, et al. The prevalence of multimorbidity in primary care and its effect on health care utilization and cost. Fam Pract 2011; 28:516-23.

9. Nunes BP, Flores TR, Mielke GI, Thumé E, Facchini LA. Multimorbidity and mortality in older adults: a systematic review and meta-analysis. Arch Gerontol Geriatr 2016; 67:130-8.

10. Fortin M, Stewart M, Poitras M-E, Almirall J, Maddocks H. A systematic review of prevalence studies on multimorbidity: toward a more uniform methodology. Ann Fam Med 2012; 10:142-51.

11. Jerliu N, Toçi E, Burazeri G, Ramadani N, Brand $\mathrm{H}$. Prevalence and socioeconomic correlates of chronic morbidity among elderly people in Kosovo: a population-based survey. BMC Geriatr 2013; 13:22.

12. Agborsangaya CB, Lau D, Lahtinen M, Cooke T, Johnson JA. Multimorbidity prevalence and patterns across socioeconomic determinants: a cross-sectional survey. BMC Public Health 2012; 12:201.

13. Orueta JF, Nuño-Solinís R, García-Alvarez A, Alonso-Morán E. Prevalence of multimorbidity according to the deprivation level among the elderly in the Basque Country. BMC Public Health 2013; 13:918.
14. Schäfer I, Hansen H, Schön G, Höfels S, Altiner A, Dahlhaus A, et al. The influence of age, gender and socio-economic status on multimorbidity patterns in primary care. First results from the multicare cohort study. BMC Health Serv Res 2012; 12:89.

15. Shadmi E. Multimorbidity and equity in health. Int J Equity Health 2013; 12:59.

16. Conway DI, Petticrew M, Marlborough H, Berthiller J, Hashibe M, Macpherson LM. Socioeconomic inequalities and oral cancer risk: a systematic review and meta-analysis of casecontrol studies. Int J Cancer 2008; 122:2811-9.

17. Lorant V, Deliège D, Eaton W, Robert A, Philippot P, Ansseau M. Socioeconomic inequalities in depression: a meta-analysis. Am J Epidemiol 2003; 157:98-112.

18. Instituto Brasileiro de Geografia e Estatística. Censo Demográfico 2010: características da população e dos domicílios - resultados do universo. Rio de Janeiro: Instituto Brasileiro de Geografia e Estatística; 2011.

19. Barros AJ, Menezes AMB, Santos IS, Assunção MCF, Gigante D, Fassa AG, et al. O Mestrado do Programa de Pós-graduação em Epidemiologia da UFPel baseado em consórcio de pesquisa: uma experiência inovadora. Rev Bras Epidemiol 2008; 11 Suppl 1:133-44.

20. Harrison C, Britt H, Miller G, Henderson J. Examining different measures of multimorbidity, using a large prospective cross-sectional study in Australian general practice. BMJ Open 2014; 4:e004694.

21. Barros AJD, Victora CG. Indicador econômico para o Brasil baseado no censo demográfico de 2000. Rev Saúde Pública 2005; 39:523-9.

22. Schäfer I, von Leitner E-C, Schön G, Koller D, Hansen H, Kolonko T, et al. Multimorbidity patterns in the elderly: a new approach of disease clustering identifies complex interrelations between chronic conditions. PLoS One 2010; 5:e15941.

23. Kaiser HF. A second-generation little jiffy. Psychometrika 1970; 35:401-15.

24. Kaiser HF, Rice J. Little Jiffy, Mark IV. Educ Psychol Meas 1974; 34:111-7.

25. Bartlett MS. Tests of significance in factor analysis. Br J Psychol 1950; 3(Part II):77-85.

26. Mackenbach JP, Kunst AE. Measuring the magnitude of socio-economic inequalities in health: an overview of available measures illustrated with two examples from Europe. Soc Sci Med 1997; 44:757-71.

27. Regidor E. Measures of health inequalities: part 2. J Epidemiol Community Health 2004; 58:900-3.

28. Nunes BP, Thumé E, Facchini LA. Multimorbidity in older adults: magnitude and challenges for the Brazilian health system. BMC Public Health 2015; 15:1172.

29. Afshar S, Roderick PJ, Kowal P, Dimitrov BD, Hill AG. Multimorbidity and the inequalities of global ageing: a cross-sectional study of 28 countries using the World Health Surveys. BMC Public Health 2015; 15:776. 
30. van den Bussche H, Koller D, Kolonko T, Hansen $\mathrm{H}$, Wegscheider K, Glaeske G, et al. Which chronic diseases and disease combinations are specific to multimorbidity in the elderly? Results of a claims data based cross-sectional study in Germany. BMC Public Health 2011; 11:101.

31. Marengoni A, Winblad B, Karp A, Fratiglioni L. Prevalence of chronic diseases and multimorbidity among the elderly population in Sweden. Am J Public Health 2008; 98:1198200.

32. Fortin M, Hudon C, Haggerty J, van den Akker M, Almirall J. Prevalence estimates of multimorbidity: a comparative study of two sources. BMC Health Serv Res 2010; 10:111.

33. Agborsangaya CB, Ngwakongnwi E, Lahtinen M, Cooke T, Johnson JA. Multimorbidity prevalence in the general population: the role of obesity in chronic disease clustering. BMC Public Health 2013; 13:1161.

34. Garin N, Koyanagi A, Chatterji S, Tyrovolas S, Olaya B, Leonardi M, et al. Global multimorbidity patterns: a cross-sectional, populationbased, multi-country study. J Gerontol A Biol Sci Med Sci 2016; 71:205-14.

35. He Y, Zhang M, Lin EH, Bruffaerts R, Posada-Villa J, Angermeyer MC, et al. Mental disorders among persons with arthritis: results from the World Mental Health Surveys. Psychol Med 2008; 38:1639-50.

36. Schmidt MI, Duncan BB, Azevedo e Silva G, Menezes AM, Monteiro CA, Barreto SM, et al. Chronic non-communicable diseases in Brazil: burden and current challenges. Lancet 2011; 377:1949-61.
37. Beaglehole R, Bonita R, Horton R, Adams C, Alleyne G, Asaria P, et al. Priority actions for the non-communicable disease crisis. Lancet 2011; 377:1438-47.

38. Nunes BP, Thumé E, Tomasi E, Duro SMS, Facchini LA. Socioeconomic inequalities in the access to and quality of health care services. Rev Saúde Pública 2014; 48:968-76.

39. Mackenbach JP. An analysis of the role of health care in reducing socioeconomic inequalities in health: the case of the Netherlands. Int J Health Serv 2003; 33:523-41.

40. Hosseinpoor AR, Bergen N, Mendis S, Harper $S$, Verdes E, Kunst A, et al. Socioeconomic inequality in the prevalence of noncommunicable diseases in low-and middle-income countries: results from the World Health Survey. BMC Public Health 2012; 12:474.

41. Rzewuska M, de Azevedo-Marques JM, Coxon D, Zanetti ML, Zanetti ACG, Franco LJ, et al. Epidemiology of multimorbidity within the Brazilian adult general population: evidence from the 2013 National Health Survey (PNS 2013). PLoS One 2017; 12:e0171813.

42. Vellakkal S, Millett C, Basu S, Khan Z, AitsiSelmi A, Stuckler D, et al. Are estimates of socioeconomic inequalities in chronic disease artefactually narrowed by self-reported measures of prevalence in low-income and middleincome countries? Findings from the WHOSAGE survey. J Epidemiol Community Health 2015; 69:218-25. 


\section{Resumo}

O nível socioeconômico baixo está relacionado diretamente à multimorbidade, e é possível que a aglomeração de morbidades apresente a mesma associação. O estudo teve como objetivo identificar a prevalência da multimorbidade e de clusters de morbidades entre idosos, além das desigualdades socioeconômicas subjacentes. Este foi um estudo transversal de base populacional em indivíduos com 60 anos ou mais. Multimorbidade foi definida como a presença de 2+, 3+, 4+ ou 5+ condições de saúde no mesmo individuo. O nível de escolaridade e o Indice Econômico Nacional foram usados para medir desigualdades na prevalência de multimorbidade entre idosos. Foram utilizados os indices de desigualdades slope $e$ concentration para avaliar as diferenças absolutas e relativas. A análise fatorial foi realizada para identificar clusters de doenças. Em cada dez idosos, nove, oito, sete e seis apresentavam 2+, 3+, 4+ e 5+ condições de saúde, respectivamente. Foram identificados três clusters de morbidades, correspondendo aos transtornos musculoesqueléticos/mentais/funcionais e doenças cardiometabólicas e respiratórias. Maiores desigualdades foram encontradas para o maior número de condições de saúde (5+), considerando nível economômico, e para 3+, 4+ e 5+, considerando nível de escolaridade. Os achados revelam a alta prevalência de multimorbidade entre idosos, destacando a persistência de desigualdades de saúde no Sul do Brasil. As estratégias dos serviços de saúde devem priorizar os idosos de nível socioeconômico mais baixo.

Multimorbidade; Iniquidade Social; Idoso

\section{Resumen}

Un nivel socioeconómico más bajo está positivamente relacionado con la multimorbilidad y es posible que la acumulación de estos problemas de salud provenga de esta misma asociación. El objetivo de este estudio fue identificar la prevalencia de multimorbilidad y los grupos de afecciones de salud entre ancianos, así como sus inequidades socioeconómicas subyacentes. Se trata de un estudio transversal, basado en población, que se llevó a cabo con personas de 60 años. Multimorbilidad se definió como la presencia de 2+, 3+, 4+ ó 5+ condiciones de salud en el mismo individuo. Los niveles de escolaridad y el Índice Económico Nacional fueron utilizados para investigar inequidades en la prevalencia de multimorbilidad entre ancianos. Los indices de inequidad slope $y$ concentration se usaron para evaluar las diferencias absolutas y relativas. Se realizó un análisis factorial para identificar los grupos de enfermedades. En cada diez ancianos, nueve, ocho, siete y seis tenían 2+, $3+, 4+y 5+$ condiciones de salud, respectivamente. Se encontraron tres grupos de afecciones de salud, que conllevaban enfermedades musculoesquelético/mental/funcionales, cardiometabólicas, además de factores respiratorios. Se encontraron mayores desigualdades para el mayor número de condiciones de salud (5+), cuando se consideraba el nivel económico, y para 3+, 4+ y 5+, cuando se tenía en consideración el nivel educativo. Estos hallazgos mostraron una alta prevalencia de multimorbilidad entre adultos de avanzada edad, resaltando la persistencia de inequidades de salud en el sur de Brasil. Las estrategias por parte de los servicios de salud necesitan centrarse en ancianos con niveles socioeconómicos más bajos.

Multimorbilidad; Inequidad Social; Anciano
Submitted on 05/Mar/2018

Final version resubmitted on 01/Jun/2018 Approved on 14/Jun/2018 